\title{
PENGARUH KEMAMPUAN KERJA DAN LINGKUNGAN KERJA TERHADAP KINERJA PEGAWAI PADA BADAN PENANGGULANGAN BENCANA DAERAH KABUPATEN MUSI RAWAS
}

\author{
THE INFLUENCE OF ABILITY AND WORK ENVIRONMENT ON \\ EMPLOYEES' PERFORMANCE IN REGIONAL DISASTER MANAGEMENT \\ BOARD, MUSI RAWAS REGENCY
}

\author{
Suyadi \\ Sekolah Tinggi Ilmu Ekonomi Musi Rawas \\ Jl. Yos Sudarso Km. 13 Lubuk Kupang Kec. Lubuklinggau Selatan 1 Kota Lubuk linggau \\ Sumatera Selatan 36125 \\ e-mail: suyadimm7@gmail.com
}

Naskah diterima 02 Juli 2018, di-review 01 Agustus 2018, disetujui 09 Nopember 2018

\begin{abstract}
This study aims to determine the ability and work environment on the performance of employees at the Regional Disaster Management Board of Musi Rawas Regency. The population was 54 employees. Data were collected through questionnaires, and analyzed by using simple linear test, correlation coefficient, $t$ test, multiple regression, determination coefficient, and $F$ test. The research findings reflected couple things. First, there is a significant influence of the employees' ability towards their performance partially in Regional Disaster Management Board of Musi Rawas Regency. It is supported by the simple partial regression test results is equal to 27.903. Testing Hypothesis Test is 2,957 $\geq t$ table 1,673. Second, there is a significant influence of the employees' work environment towards their performance partially in Regional Disaster Management Board of Musi Rawas Regency. It is proofed by simple partial regression test results is equal to 0.556. Testing Hypothesis Test is 2,957 $\geq$ t table 1,673. Third, there are significance influence of both the employees' ability and work environment towards their performance all together in Regional Disaster Management Board of Musi Rawas Regency. It is explained through hypothesis Test Testing with F test obtains F count value of 42.721 and the level of significance simultaneously sig F is $0.000 \alpha \alpha(0.05)$.
\end{abstract}

Keywords: employees' performance, ability, and work environment

Abstrak: Penelitian ini bertujuan untuk mengetahui kemampuan kerja dan lingkungan lingkungan kerja terhadap kinerja pegawai pada Badan Penanggulangan Bencana Daerah Kabupaten Musi Rawas. Populasi Penelitian ini berjumlah 54 orang pegawai dan teknik pengumpulan data mengunakan kuisioner (angket), serta teknik analisis data yang digunakan adalah uji linear sederhana, koefisien korelasi, uji T, regresi berganda, koefisien determinasi, dan uji F. Dimana peneliti mengunakan bantuan program SPSS. Pengujian hasil uji regresi sederhana secara parsial antara variabel bebas Kemampuan Kerja terhadap variabel terikat Kinerja Pegawai pada Badan Penanggulangan Bencana Daerah Kabupaten Musi Rawas yaitu a sebesar 27,903 sedangkan b sebesar 0,556. Sedangkan Lingkungan Kerja juga terhadap variabel terikat Kinerja Pegawai pada Badan Penanggulangan Bencana Daerah Kabupaten Musi Rawas yaitu a sebesar 23,170 sedangkan b sebesar 0,622. Jika Badan Penanggulangan Bencana Daerah Kabupaten Musi Rawas meningkatkan Kemampuan Kerja dan Lingkungan Kerja maka meningkatkan kinerja pegawai. Hasil uji Kemampuan Kerja berkorelasi kuat terhadap variabel terikat Kinerja pegawai pada Badan Penanggulangan Bencana Daerah Kabupaten Musi Rawas yaitu sebesar 6,76\% (R=0,676). Sedangkan Lingkungan Kerja juga berkorelasi kuat terhadap variabel terikat Kinerja pegawai pada Badan Penanggulangan Bencana Daerah Kabupaten Musi Rawas yaitu sebesar 76,0\% (R=0,750). Pengujian Uji Hipotesis secara parsial Kemampuan Kerja terhadap variabel terikat Kinerja pegawai pada Badan Penanggulangan Bencana Daerah Kabupaten Musi Rawas yaitu sebesar 2,957 $\geq \mathrm{t}_{\text {tabel }} 1,673$. Sedangkan Uji Hipotesis secara parsial variabel bebas Lingkungan Kerja terhadap variabel terikat Kinerja Pegawai pada Badan Penanggulangan Bencana Daerah Kabupaten Musi Rawas yaitu sebesar 4,810 $\geq(1,673)$ pada taraf signifikan 5\%, maka secara parsial 
variabel bebas memiliki pengaruh yang signifikan terhadap variabel terikat. Kemudian variasi perubahan Kinerja Pegawai dapat dijelaskan oleh Kemampuan Kerja dan Lingkungan Kerja secara simultan sebesar $62,6 \%$ dan sisanya 37,4\% dipengaruhi variabel lain. Hal ini dapat diartikan apabila dilakukan perubahan secara bersama-sama maka akan dapat mempengaruhi Kinerja Pegawai Pada Badan Penanggulangan Bencana Daerah Kabupaten Musi Rawas. Pengujian Uji Hipotesis dengan uji $F$ memperoleh nilai $\mathrm{F}_{\text {hitung }}$ sebesar 42,721dan tingkat kemaknaan secara serentak sig. F adalah $0,000 \leq \alpha(0,05)$, Pada taraf signifikan 5\%, maka Kemampuan Kerja dan Lingkungan Kerja secara bersama-sama terhadap Kinerja pegawai pada Badan Penanggulangan Bencana Daerah Kabupaten Musi Rawas.

Kata kunci: kemampuan kerja, lingkungan kerja, dan kinerja pegawai

\section{PENDAHULUAN}

$I_{\mathrm{t}}$ nstansi Pemerintah didirikan dengan berbagai tujuan yang ingin dicapai. Tujuan tersebut dapat tercapai jika manajemen dapat mengolah, menggerakkan dan menggunakan sumber daya manusia yang dimilikinya secara efektif dan efisien. Keberadaan pegawai menjadi salah satu faktor penting yang dapat menentukan keberhasilan tujuan instansi tersebut. Pegawai juga menjadi penguat fungsi-fungsi organisasi dalam sebuah instansi pemerintah. Keberadaan pegawai akan dapat dilihat dari kinerja yang dihasilkannya.

Lingkungan sangat menentukan kinerja pegawai dalam sebuah perusahaan atau organisasi tersebut. Keberhasilan dan kecakapan pelaksanaan pekerjaan dalam suatu organisasi sangat bergantung pada lingkungan kerja yang dimiliki oleh pegawai. Sehingga lingkungan kerja merupakan hal penting bagi seorang pegawai untuk dapat menyelesaikan pekerjaan dengan baik. Dalam organisasi atau perusahaan, kita bisa melihat bahwa dalam penempatan pegawai atau karyawan pada umumnya semakin tinggi kedudukan seseorang dalam organisasi yang lebih diperlukan adalah kemampuan berpikir dan bukan kemampuan fisiknya. Mengenai kesanggupan seseorang memang sangat tergantung pada kondisi fisik dan jiwanya, yang akhirnya akan mempengaruhi tingkat kemampuan dalam melaksanakan pekerjaannya. Lingkungan kerja yang terlihat pada kenyataan menunjukkan bahwa masih ada pegawai yang telah mengetahui tugasnya, akan tetapi dalam melaksanakan tugasnya masih belum maksimal. Terkadang mereka malas dalam melaksanakan tugasnya. Lingkungan kerja sangat menentukan kinerja pegawai dalam sebuah organisasi tersebut. Keberhasilan dan kecakapan pelaksanaan pekerjaan dalam suatu organisasi sangat bergantung pada lingkungan kerja yang dimiliki oleh pegawai. Sehingga lingkungan kerja merupakan hal penting bagi seorang pegawai untuk dapat menyelesaikan pekerjaan dengan baik. Kinerja yang baik tentunya juga dipengaruhi oleh kemampuan kerja pegawai dan juga lingkungan. Kemampuan kerja atau sering disebut dengan kompetensi. Kompetensi adalah suatu kemampuan untuk melaksanakan atau melakukan suatu pekerjaan sikap kerja yang dituntut oleh pekerjaan tersebut (Wibowo, 2011: 324).

Badan Penanggulangan Bencana Daerah Kabupaten Musi Rawas merupakan instansi yang memiliki tugas pokok dan fungsi yaitu membantu bupati dalam menyelenggarakan pemerintah daerah di bidang penanggulangan bencana berdasarkan Peraturan Bupati Kabupaten Musi Rawas No. 13 Tahun 2014 tanggal 15 Juli 2014 tentang Penjabaran 
Tugas Pokok dan Fungsi Badan Penanggulangan Bencana Daerah Kabupaten Musi Rawas. Dalam menjalankan tugasnya Badan Penanggulangan Bencana Daerah Kabupaten Musi Rawas memiliki visi yaitu "Menjadikan BPBD yang Profesional untuk Mewujudkan Masyarakat Musi Rawas yang Tangguh Menghadapi Bencana". Dalam menjalankan tugasnya pegawai Badan Penanggulangan Bencana Daerah Kabupaten Musi Rawas terkadang masih mengalami kesulitan dalam menyelesaikan pekerjaan yang diberikan, karena kemampuan kerja yang masih belum optimal dikarenakan latar pendidikan pegawai yang terkadang tidak sesuai dengan jabatan atau tugas yang diberikan

\section{Rumusan Masalah}

1. Bagaimana pengaruh kemampuan kerja terhadap kinerja pada Badan Penanggulangan Bencana Daerah Kabupaten Musi Rawas ?

2. Bagaimana pengaruhlingkungan kerja terhadap kinerja pada Badan Penanggulp Penangulangan Bencana Daerah Kabupaten Musi Rawas?

3. Bagaimana pengaruh kemampuan kerja dan lingkungan kerja terhadap kinerja pada Badan Penanggulangan Bencana Daerah Kabupaten Musi Rawas?

\section{Kerangka Konseptual}

\section{Definisi Kemampuan Kerja}

Kemampuan atau kompetensi adalah suatu yang mendasari karakteristik dari suatu individu yang dihubungkan dengan hasil yang diperoleh dalam suatu pekerjaan (Sutrisno, 2015: 202). Kompetensi adalah suatu kapasitas individu untuk mengerjakan berbagai tugas dalam suatu pekerjaan (Sutrisno, 2015: 202). Proses kompetensi adalah suatu fungsi yang penting dalam proses organisasi maupun dengan tujuantujuan yang antara lain meliputi pemakaian sumber daya manusia maupun sumber-sumber daya bukan manusia secara efektif.

Untari (2015: 2) menjelaskan bahwa kompetensi merupakan variabel utama yang harus dimiliki oleh seorang karyawan dalam melaksanakan pekerjaannya, sehingga dengan adanya kompetensi yang telah dimiliki dapat membantu para karyawan di dalam menyelesaikan pekerjaan sesuai dengan target yang telah ditentukan. Sedangkan Menurut (Untari, 2015: 5) indikator kemampuan (kompetensi) meliputi:

1. Pengetahuan

Pengetahuan yang dimiliki seseorang akan membantunya dalam menyelesaikan pekerjaan yang diberikan.

2. Keterampilan

Keterampilan yang dimiliki akan mempermudah karyawan dalam mencari solusi terhadap permasalahan pekerjaan yang dihadapinya.

3. Pengalaman

Pengalaman kerja yang dimiliki karyawan akan membantu dalam menyelesaikan tugas yang diberikan kepadanya.

4. Kecakapan

Kecakapan menjadi nilai tambah bagi karyawan dalam menjalankan tugas yang diberikan kepadanya.

\section{Definisi Lingkungan Kerja}

Lingkungan kerja adalah segala sesuatu yang ada di sekitar para pekerja yang mempengaruhi dirinya 
dalam menjalani tugas-tugas yang dibebankan.

Lingkungan perusahaan yang mempengaruhi perkembangan perusahaan dapat dikelompokkan menjadi dua yaitu lingkungan umum dan lingkungan khusus (Wijayanti, 2012: 53).

Menurut (Rahmawanti, 2014: 2) menjelaskan bahwalingkungan kerja adalah salah satu komponen terpenting dalam karyawan menyelesaikan pekerjaannya. Di sini yang dimaksud lingkungan kerja adalah segala sesuatu yang ada di sekitar para pekerja yang dapat mempengaruhi dirinya dalam menjalankan tugas-tugas yang dibebankan.

Adapun indikator Lingkungan Kerja yang digunakan dalam penelitian ini menurut (Soedarmayanti, dalam Surjosuseno 2015: 86) sebagai berikut:

1. Suasana kerja

Setiap karyawan selalu menginginkan suasana kerja yang menyenangkan, Suasana kerja yang nyaman itu meliputi cahaya/penerangan yang jelas, suara yang tidak bising dan tenang, keamanan di dalam bekerja

2. Hubungan dengan rekan kerja

Salah satu faktor yang dapat mempengaruhi karyawan tetap tinggal dalam satu organisasi adalah adanya hubungan yang harmonis diantara rekan kerja

3. Tersedianya fasilitas kerja

Hal ini dimaksudkan bahwa peralatan yang digunakan untuk mendukung kelancaran kerja yaitu lengkap dan mutakhir. Tersedia fasilitas kerja yang lengkap, walaupun tidak canggih dan modern merupakan salah satu penunjang proses kelancaran dalam bekerja.

\section{Definisi Kinerja}

Pada umumnya, kinerja diberi batasan sebagai kesuksesan seseorang di dalam melaksanakan suatu pekerjaan. Kinerja adalah hasil kerja yang dapat dicapai oleh seseorang atau sekelompok orang dalam suatu organisasi, sesuai dengan wewenang dan tanggung jawab masing-masing, dalam rangka upaya mencapai tujuan organisasi bersangkutan secara legal, tidak melanggar hukum dan sesuai dengan moral maupun etika (Wibowo, 2014: 17).

Menurut (Timple, dalam Manungkunegara 2009:15) faktor yang mempengaruhi kerja adalah:

\section{Faktor Internal}

Faktor internal yaitu faktor yang dihubungkan dengan sifat-sifat seseorang. Misalnya, kerja seseorang baik disebabkan karena mempunyai kemampuan tinggi dan seseorang itu tipe pekerja keras, sedang seseorang mempunyai kinerja jelek disebabkan orang tersebut mempunyai kemampuan rendah dan orang tersebut tidak memiliki upayaupaya untuk memperbaiki kemampuannya.

\section{Faktor Eksternal}

Faktor eksternal yaitu faktor-faktor yang mempengaruhi kinerja sesorang yang berasal dari lingkungan. Seperti perilaku, sikap, dan tindakan-tindakan rekan kerja, bawahan atau pimpinan, fasilitas kerja, dan iklim organisasi. Menurut (Wibowo, 2014: 86-88) terdapat tujuh indikator kinerja yaitu:

a. Tujuan

Tujuan merupakan keadaan yang berbeda yang secaraaktif dicari oleh seorang individu atau organisasi untuk dicapai. Tujuan 
merupakan suatu keadaan yang lebih baik yang ingin dicapai di masa yangakan datang.

b. Standar

Standar merupakan suatu ukuran apakah tujuan yang diinginkan dapat dicapai tanpa standar, tidak dapat diketahui kapan suatu tujuan tercapai.

c. Umpan balik

Umpan balik melaporkan kemajuan, baik kuatitasmaupun kuuantitas, dalam mencapai tujuan yang didefinisikan oleh standar. Umpan balik terutama penting ketika kita mempertimbangkan tujuan sebenarnya.

d. Alat atau sarana

Alat atau sarana merupakan sumber daya yang dapat dipergunakan untuk membantu menyelesaikan tujuan dengan sukses dan merupakan faktor penunjang untuk pencapaian tujuan.

e. Kompetensi

Kompetensi merupakan kemampuan yang dimiliki oleh seseorang untuk menjalankan pekerjaan yang diberikan kepadanya dengan baik. f. Motif

Motif merupakan alasan atau pendorong bagi seseorang untuk melakukan sesuatu menejer memfasilitasi motivasi eksternal kepada pegawai dengan insentif berupa uang, memberi pengakuan, menetapkan tujuan menantang, menetapkan standar terjangkau, meminta umpan balik, memberikan kebebasan melakukan perkerjaan termasuk waktu melakukan pekerjaan.

g. Peluang

Pekerjaan perlu mendapat kesempatan untuk menunjukan pretasi kerjanya. Terdapat dua faktoryang menyumbangkan pada adanya kekurangan kesempatan untuk berpretasi, yaitu ketersediaan waktu dan kemampuan untuk memenuhi syarat.

\section{Kerangka Pemikiran}

Berdasarkan uraian di atas, maka kerangka berfikir dalam penelitian ini dapat digambarkan sebagai berikut:

Kemampuan Kerja $\left(\mathrm{X}_{1}\right)(1)$

Indikatornya:

1.Pengetahuan

2.Keterampilan

3.Pengalaman

4.Kecakapan

5. Kompetensi

6. Motif

7. Peluang

Gambar .1

Kerangka Pemikiran Penelitian Sumber: Olahan Peneliti 
Hipotesis dalam penelitian ini sebagai berikut :

1. Diduga ada pengaruh yang signifikan kemampuan kerja terhadap kinerja pegawai pada Badan Penanggulangan Bencana Daerah Kabupaten Musi Rawas.

2. Diduga ada pengaruh yang signifikan lingkungan kerja pegawai terhadap kinerja pegawai pada Badan Penanggulangan Bencana Daerah Kabupaten Musi Rawas.

3. Diduga ada pengaruh yang signifikan kemampuan kerja dan lingkungan kerja pegawai terhadap kinerja pegawai pada Badan Penanggulangan Bencana Daerah Kabupaten Musi Rawas.

\section{METODE PENELITIAN}

\section{Populasi dan Sampel}

\section{Populasi}

Populasi adalah wilayah generalisasi yang terdiri atas obyek/subyek yang mempunyai kualitas dan karakter tertentu yang diterapkan oleh peneliti untuk dipelajari dan kemudian ditarik kesimpulannya (Sugiyono, 2013: 90). Populasi adalah sekumpulan orang, kejadian atau segala sesuatu yang mempunyai karakteristik tertentu. Populasi dalam penelitian ini seluruh objek penelitian berjumlah 54 pegawai terdiri dari 15 orang PNS dan 39 orang TKST dan honorer yang terdiri dari 1 orang kepala kantor, 1 orang sekretaris, 2 orang kasi, 11 orang staff BPBD, 37 orang TKST Tim Reaksi Cepat Penanggulangan Bencana, dan 2 orang operator.

\section{Sampel}

Sampel adalah bagian dari jumlah dan karakteristikyang memiliki oleh populasi tersebut (Sugiyono, 2013: 91). Karena populasinya 54 orang maka sampel yang digunakan adalah sampel jenuh adalah semua pegawai yaitu 54 orang.

\section{Sumber Data \\ Data primer}

Data dalam penelitian ini diperoleh dari observasi, kuesioner dan wawancara yang berkaitan dengan kemampuan kerja dan lingkungan kerja pegawai terhadap kinerja pegawai pada Badan Penanggulangan Bencana Daerah Kabupaten Musi Rawas.

\section{Data sekunder}

Data sekunder dalam penelitian ini diperoleh dari dokumentasi yang ada pada Badan Penanggulangan Bencana Daerah Kabupaten Musi Rawas

\section{Teknik Analisis Data}

\section{Regresi Linear Sederhana}

Analisis regresi linear sederhana digunakan untuk mengetahui pengaruh variabel bebas yaitu kemampuan kerja atau lingkungan kerja (X) terhadap variabel terikat yaitu kinerja (Y). Untuk menentukan kesamaan dua rata-rata variabel dengan rumus sebagai berikut:

$$
\mathrm{Y}=\mathrm{a}+\mathrm{b} \text { X + e (Sugiyono, 2013:108) }
$$

Dimana :

$$
\mathrm{Y} \quad=\text { Kinerja }
$$


VOLUME 2, NOMOR 2, DESEMBER 2018

$\mathrm{X}=$ kemampuan kerja atau lingkungan kerja

$\mathrm{a} \quad=$ Konstanta

b1, b2 = Koefisien Regrasi

e $\quad=$ error term

\section{Koefisien Korelasi}

Menurut Sugiyono (2013: 213) koefisien korelasi adalah mencari hubungan antara variabel bebas kemampuan kerja atau lingkungan kerja $(\mathrm{X})$ dan variabel terikat kinerja $(\mathrm{Y})$ dengan menggunakan rumus Product Moment sebagai berikut.

$$
\mathrm{r}_{\mathrm{xy}}=\frac{N X Y(X)(Y)}{\sqrt{ }\left\{N x^{2}(X)^{2}\right\}\left\{N y^{2}(Y)^{2}\right\}}
$$

Keterangan:

$\mathrm{r}_{\mathrm{xy}}$ : Koefisien korelasi

$\mathrm{N}$ : Jumlah subjek

$\mathrm{X}$ : Kemampuan kerja atau lingkungan kerja

Y : Kinerja

Klasifikasi besarnya koefisien korelasi yang digunakan adalah sebagai berikut:

Tabel 1

Taraf Koefisien Korelasi

\begin{tabular}{|l|l|}
\hline \multicolumn{1}{|c|}{ Rentang Nilai } & \multicolumn{1}{c|}{ Keterangan } \\
\hline $0,80<R_{x y} \leq 1,00$ & Sangat baik \\
\hline $0,60<R_{x y} \leq 0,80$ & Baik \\
\hline $0,40<R_{x y} \leq 0,60$ & Cukup \\
\hline $0,20<R_{x y} \leq 0,40$ & Kurang \\
\hline $0,00<R_{x y} \leq 0,20$ & Rendah \\
\hline$r_{x y} \leq 0,00$ & Sangat rendah \\
\hline
\end{tabular}

Sumber: Arikunto, 2010:319

\section{Uji $\boldsymbol{t}$}

Uji t digunakan untuk mencari hubungan antara dua variabel. Menurut (Sugiyono, 2013: 184) uji parsial (Uji t) dilakukan untuk membuktikan hipotesis yang dihitung secara terpisah dengan membandingkan $t_{\text {Hitung }}$ dengan $\mathrm{t}_{\text {Tabel }}$ dengan rumus sebagai berikut :

$$
\mathrm{t}=\frac{r n 2}{1 r^{2}}
$$

Keterangan :

$r \quad=$ Nilai koefisien korelasi

$\mathrm{n}=$ Jumlah responden

Distribusi (tabel t) untuk $x=0,05$ dan derajat kebebasan $(\mathrm{dk}=\mathrm{n}-2)$.
Kaidah keputusannya adalah jika $t_{\text {hitung }}>t_{\text {tabel }}$ berarti diterima sebaliknya $t_{\text {hitung }} t_{\text {tabel }}$ berarti tidak diterima atau ditolak. Uji t dikatakan signifikan bila ${ }^{t}$ hitung $>{ }^{t}$ tabel ${ }_{\text {, sedangkan uji tidak signifikan jika }}{ }^{\text {thitung }}<{ }^{t}$ tabel.

\section{Regresi Linear Berganda}

Analisis regresi linear berganda digunakan untuk mengetahui pengaruh variabel bebas yaitu kemampuan kerja (X1) dan lingkungan kerja (X2) terhadap variabel terikat yaitu kinerja pegawai (Y). Untuk menentukan kesamaan dua rata-rata variabel dengan rumus sebagai berikut: (Sugiyono, 2013:108)

Dimana :

$$
y=a+b 1 X 1+b 2 X 2
$$

$\mathrm{Y}=$ kinerja

$\mathrm{X} 1$ = kemampuan kerja 


\section{Koefisien Determinasi}

Digunakan untuk mengetahui persentase sumbangan antara variabel bebas independen yaitu kemampuan kerja $\left(\mathrm{X}_{1}\right)$ atau lingkungan kerja $\left(\mathrm{X}_{2}\right)$ dan variabel terikat dependen yaitu kinerja $(\mathrm{Y})$ dengan rumus :

$$
R^{2}=\underline{b}_{1} \underline{X}_{1} \underline{Y b}_{2} \underline{X}_{2} \underline{y}
$$

Dimana :

$R^{2}=$ Koefisien Determinasi

$b_{1}=$ Keofisien Korelasi kemampuan kerja

$b_{2}=$ Korelasi lingkungan kerja

\section{Uji F}

Uji F digunakan untuk mengetahui apakah variabel independen secara kemampuan kerja $\left(\mathrm{X}_{1}\right)$ atau Lingkungan Kerja $\left(\mathrm{X}_{2}\right)$ secara bersama-sama berpengaruh secara signifikan terhadap variabel dependen (Y). Untuk menguji signifikansi dengan membandingkan $\mathrm{F}_{\text {hitung }}$ dengan $\mathrm{F}_{\text {tabel }}$

$$
\begin{aligned}
& \text { Fhitung }=\underline{R}^{2} n m 1 \\
& m 1 R^{2}
\end{aligned}
$$

Dimana :

$\mathrm{R}^{2} \quad$ : Nilai Regresi

m : Jumlah variabel bebas

$\mathrm{n} \quad$ : Jumlah responden

Jika :

$\mathrm{F}_{\text {hitung }} \geq \mathrm{F}_{\text {tabel }}$ maka tolak Ho artinya signifikan

$\mathrm{F}_{\text {hitung }} \leq \mathrm{F}_{\text {tabel' }}$ maka terima Ha artinya tidak signifikan

$\mathrm{F}$ tabel $=\mathrm{F}(1-\alpha)(\mathrm{dk}$ pembilang $=\mathrm{m})(\mathrm{dk}$ penyebut

$=\mathrm{n}-\mathrm{m}-1)$

118 | Suyadi
Untuk mengetahui besarnya koefisien regresi dapat dilakukan hipotesis regresi secara bersama-sama dengan menggunakan analisis varian uji F melalui prosedur sebagai berikut:

Ho: $p=0$, Menunjukan bahwa ada pengaruh yang signifikan kemampuan kerja dan lingkungan kerja terhadap kinerja pada Badan Penanggulangan Bencana Daerah Kabupaten Musi Rawas

Ha: $p \neq 0$, Menunjukan bahwa tidak ada pengaruh yang signifikan kemampuan kerja dan lingkungan kerja terhadap kinerja pada Badan Penanggulangan Bencana Daerah Kabupaten Musi Rawas

Untuk menentukan kriteria penerimaan hipotesis, apabila Fhitung > Ftabel maka Ho ditolak dan Ha diterima, artinya signifikan sedangkan apabila Fhitung < Ftabel, maka Ho diterima dan Ha ditolak, artinya signifikan.

\section{PEMBAHASAN DAN HASIL}

\section{Uji Regresi Linear Sederhana}

Metode perhitungan regresi linier sederhana digunakan dengan tujuan untuk mencari hasil jawaban responden dari penyebaran kuisioner yang diberikan kepada 54 pegawai pada pada Badan Penanggulangan Bencana Daerah Kabupaten Musi Rawas. Hasil uji secara rinci akan disajikan pada tabel 4.58 di bawah ini: 
Tabel 2

Hasil uji Regresi Linear Sederhana Variabel Kemampuan Kerja ( $\mathrm{X}_{1}$ ) Terhadap Kinerja Pegawai (Y) Coefficients

\begin{tabular}{|c|c|c|c|c|c|}
\hline & & \multicolumn{2}{|c|}{ Unstandardized Coefficients } & Standardized Coefficients & \multirow[b]{2}{*}{ Sig. } \\
\hline \multicolumn{2}{|c|}{ Model } & B & Std. Error & Beta & \\
\hline 1 & (Constant) & 27.903 & 4.980 & & .000 \\
\hline & $\mathrm{X}_{1}$ & .556 & .084 & .676 & .000 \\
\hline
\end{tabular}

Sumber : Hasil Olahan Data, Tahun 2017, SPSS versi 17.

Hasil penelitian menunjukan bahwa nilai a akan sebesar 27,903 sedangkan b sebesar 0,556 sebesar 27,903 dan nilai b sebesar 0,556 sesuai jika pegawai pada Badan Penanggulangan Bencana dengan persamaan $\mathrm{Y}=\mathrm{a}+\mathrm{bX}$ maka dapat diketahui Daerah Kabupaten Musi Rawas meningkatkan jikaY=27,903+0,556 $\mathrm{X}_{1}$ jadi a =27,903 artinya tanpa Kemampuan Kerja sebesar 1 satuan maka akan adanya Kemampuan Kerja maka Kinerja pegawai meningkatkan Kinerja pegawai sebesar 0,556.

Tabel 3

Hasil uji Regresi Linear Sederhana Variabel Lingkungan Kerja $\left(\mathrm{X}_{2}\right)$ Terhadap Kinerja Pegawai (Y) Coefficients $^{\mathrm{a}}$

\begin{tabular}{|l|l|l|l|l|l|}
\hline \multicolumn{2}{|l|}{} & \multicolumn{2}{|l|}{ Unstandardized Coefficients } & Standardized Coefficients & \\
\hline \multicolumn{2}{|l|}{ Model } & B & Std. Error & Beta & Sig. \\
\hline 1 & (Constant) & 23.170 & 4.610 & & .000 \\
\hline & $\mathrm{X}_{2}$ & .622 & .076 & .750 & .000 \\
\hline
\end{tabular}

Sumber : Hasil Olahan Data, Tahun 2017, SPSS versi 17

Hasil penelitian menunjukan bahwa nilai a sebesar 23,170 dan nilai b sebesar 0,622 sesuai dengan persamaan $\mathrm{Y}=\mathrm{a}+\mathrm{bX}$ maka dapat diketahui jika $Y=23,170+0,622 X$ jadi $a=23,170$ artinya pegawai pada Badan Penanggulangan Bencana Daerah Kabupaten Musi Rawas tanpa adanya Lingkungan Kerjamaka Kinerja pegawai akan sebesar 23,170, sedangkan b sebesar 0,622 jika Pada Badan Penanggulangan Bencana Daerah Kabupaten Musi Rawas meningkatkan Lingkungan
Kerja sebesar 1 satuan maka akan meningkatkan Kinerja pegawai sebesar 0,622.

\section{Uji Koefisien Korelasi (R)}

Koefisien Korelasi digunakan untuk mencari seberapa besar erat hubungan antara variabel bebas (Kemampuan Kerja dan Motivasi Kerja) dengan variabel terikat (Kinerja Pegawai Pada Badan Penanggulangan Bencana Daerah Kabupaten Musi Rawas), dengan menggunakan program SPSS 17.0 for windows dapat dilihat pada tabel berikut:

Tabel 4

Hasil Uji Koefisien Korelasi (R) Variabel Kemampuan Kerja $\left(\mathrm{X}_{1}\right)$ Terhadap Kinerja Pegawai (Y) Model Summary ${ }^{\mathrm{b}}$

\begin{tabular}{|l|l|l|l|l|}
\hline Model & R & R Square & Adjusted R Square & Std. Error of the Estimate \\
\hline 1 & $.67 a$ & .457 & .446 & 3.38041 \\
\hline
\end{tabular}

Sumber : Hasil Olahan Data, Tahun 2017, SPSS versi 17. 
JURNAL IMARA

Hasil penelitian menunjukan bahwa koefisien korelasi antara Kemampuan Kerja terhadap dinyatakan kuat antara variabel Kemampuan Kinerja Pegawai adalah nilai R sebesar 0,676

Kerja dengan Kinerja Pegawai.

Tabel 5

Hasil Uji Koefisien Korelasi (R) Variabel Lingkungan Kerja( $\mathrm{X}_{2}$ ) Terhadap Kinerja Pegawai (Y) Model Summary

\begin{tabular}{|l|l|l|l|l|}
\hline Model & R & R Square & Adjusted R Square & Std. Error of the Estimate \\
\hline 1 & $.750 \mathrm{a}$ & .562 & .554 & 3.03471 \\
\hline
\end{tabular}

Sumber : Hasil Olahan Data, Tahun 2017, SPSS versi 17.

Hasil penelitian menunjukan bahwa koefisien korelasi antara Lingkungan Kerja terhadap Kinerja Pegawai adalah nilai R sebesar 0,750 dinyatakan kuat antara variabel Lingkungan Kerja dengan Kinerja Pegawai.

\section{Uji T (Parsial)}

Uji T dilakukan untuk membuktikan hipotesis apakah Kemampuan Kerja berpengaruh terhadap Kinerja Pegawai Pada Badan Penanggulangan
Bencana Daerah Kabupaten Musi Rawas apakah Lingkungan Kerja berpengaruh terhadap Kinerja Pegawai Pada Badan Penanggulangan Bencana Daerah Kabupaten Musi Rawas dengan membandingkan $t_{\text {hitung }}$ dengan $t_{\text {tabel }}$ dilakukan penelitian untuk mengetahui apakah hipotesis diterima atau ditolak sesuai dengan kriteria yaitu. Jika $t_{\text {hitung }}>\mathrm{t}_{\text {tabel }}$ maka Ho ditolak dan Ha diterima sebaliknya jika $\mathrm{t}_{\text {hitung }}<\mathrm{t}_{\text {tabel, }}$ maka Ho diterima dan Ha di tolak. Adapun hasil penelitian sebagai berikut:

Tabel 6

Hasil Uji T (Parsial) Hubungan antara Kemampuan( $\mathrm{X}_{1}$ ) Terhadap Kinerja Pegawai (Y) Coefficients $^{\mathrm{a}}$

\begin{tabular}{|l|l|l|}
\hline \multicolumn{1}{|c|}{ Model } & \multicolumn{1}{c|}{ T } & \multicolumn{1}{c|}{ Sig. } \\
\hline 1 (Constant) & 3.802 & .000 \\
\hline Kemampuan Kerja (X1) & 2.957 & .005 \\
\hline
\end{tabular}

Sumber : Hasil Olahan Data, Tahun 2017, SPSS versi 17.

Berdasarkan rekapitulasi hasil uji $\mathrm{T}$ di atas hubungan antara Kemampuan Kerja Terhadap Kinerja Pegawai dapat dijelaskan, bahwa :

Variabel Kemampuan Kerja terhadap Kinerja pegawai Pegawai Pada Pada Badan Penanggulangan Bencana Daerah Kabupaten Musi Rawas menunjukkan nilai $t_{\text {hitung }}=\mathbf{2 , 9 5 7}$ lebih besar dari nilai $t_{\text {tabel }}(\mathbf{1 , 6 7 3 )}$ dengan taraf signifikan $a=5 \%$. Dengan kriteria pengujian adalah jika $\mathrm{t}_{\text {hitung }}>\mathrm{t}_{\text {tabel }}$ maka Ho diterima dan jika $\mathrm{t}_{\text {hitung }}<\mathrm{t}_{\text {tabel }}$ maka Ha diterima, maka dapat diketahui bahwa $t_{\text {hitung }}>t_{\text {tabel }}$ artinya Ho ditolak dan Ha diterima bahwa terdapat adanya pengaruh variabel Kemampuan Kerja yang signifikan terhadap Kinerja pegawai Pada Pada Badan Penanggulangan Bencana Daerah Kabupaten Musi Rawas. Ini membuktikan bahwa hipotesis pertama yang berbunyi “Diduga ada pengaruh yang signifikan antara Kemampuan Kerja secara parsial terhadap Kinerja pegawai Pada Badan Penanggulangan Bencana Daerah Kabupaten Musi Rawas" terbukti dan hipotesis diterima. 
Tabel. 7

Hasil Uji T (Parsial)

Hubungan antara Lingkungan Kerja $\left(\mathrm{X}^{2}\right)$ Terhadap Kinerja Pegawai (Y)

Coefficients $^{\mathrm{a}}$

\begin{tabular}{|l|l|l|l|}
\hline \multicolumn{1}{|c|}{ Model } & \multicolumn{1}{c|}{ T } & \multicolumn{1}{c|}{ Sig. } \\
\hline 1 & (Constant) & 3.802 & .000 \\
\hline Lingkungan Kerja $\left(\mathrm{X}_{2}\right)$ & 4.810 & .000 \\
\hline
\end{tabular}

Sumber : Hasil Olahan Data, Tahun 2017, SPSS versi 17.

Berdasarkan rekapitulasi hasil uji $\mathrm{T}$ di atas hubungan antara Lingkungan KerjaTerhadap Kinerja Pegawai dapat dijelaskan, bahwa :

Variabel Lingkungan Kerja terhadap Kinerja pegawai Pegawai Pada Badan Penanggulangan Bencana Daerah Kabupaten Musi Rawas menunjukkan nilai $t_{\text {hitung }}=\mathbf{4 , 8 1 0}$ lebih besar dari nilai $t_{\text {tabel }}(\mathbf{1 , 6 7 3})$ dengan taraf signifikan $a=5 \%$. Dengan kriteria pengujian adalah jika $t_{\text {hitung }}>t_{\text {tabel }}$ maka Ho diterima dan jika $\mathrm{t}_{\text {hitung }}<\mathrm{t}_{\text {tabel }}$ makaHa diterima, maka dapat diketahui bahwa $\mathrm{t}_{\text {hitung }}>$ $\mathrm{t}_{\text {tabel }}$ artinya Ho ditolak dan Ha diterima bahwa terdapat adanya pengaruh variabel Lingkungan Kerja yang signifikan terhadap Kinerja Pegawai Pada Badan Penanggulangan Bencana Daerah Kabupaten Musi Rawas. Ini membuktikan bahwa hipotesis kedua yang berbunyi "Diduga ada

pengaruh yang signifikan antara Lingkungan Kerjasecara parsial terhadap Kinerja pegawai Pegawai Pada Badan Penanggulangan Bencana Daerah Kabupaten Musi Rawas" terbukti dan hipotesis diterima

\section{Uji Regresi Linear Berganda}

Uji regresi linear berganda digunakan untuk mengetahui pengaruh data primer yang diuji,yang berasal dari 2 variabel bebas yaitu Kemampuan Kerja dan Lingkungan Kerja terhadap Kinerja pegawai Pada Pada Badan Penanggulangan Bencana Daerah Kabupaten Musi Rawas Dalam uji ini akan digunakan alat bantu software statistik dengan program SPSS versi 17.0. Hasil uji regresi linear berganda secara rinci akan disajikan pada tabel 4.64 di bawah ini:

Tabel 8

Hasil Uji Regresi Linear Berganda Coefficients $^{\mathrm{a}}$

\begin{tabular}{|c|c|c|c|c|}
\hline \multirow[b]{2}{*}{ Model } & & Unstandardized Coefficients & & Standardized Coefficients \\
\hline & & $\mathrm{B}$ & Std. Error & Beta \\
\hline 1 & $\begin{array}{l}\text { (Constant) } \\
\mathrm{X}_{1} \\
\mathrm{X}_{2}\end{array}$ & $\begin{array}{l}17.765 \\
.272 \\
.446\end{array}$ & $\begin{array}{l}4.673 \\
.092 \\
.093 \\
\end{array}$ & $\begin{array}{l}.330 \\
.537\end{array}$ \\
\hline
\end{tabular}

Sumber : Hasil Olahan Data, Tahun 2017, SPSS versi 17

Hasil penelitian regresi liniear berganda menunjukan bahwa $\mathrm{a}=17,765, \mathrm{~b}_{1}=0,272, \mathrm{~b}_{2}=$ 0,446 berdasarkan persamaan $Y=a+b_{1} X_{1}+b_{2} X_{2}$ maka dapat diketahui bahwa $Y=17,765+0,272 X_{1}$ $+0,446 X_{2}$. Dengan analisis bahwa a sebesar 17,765 artinya jika pegawai Pada Badan Penanggulangan
Bencana Daerah Kabupaten Musi Rawas tidak melakukan tindakan ataupun kegiatan Organisasi dan Lingkungan Kerja maka Kinerja Pegawai akan sebesar 17,765 artinya jika pegawai melakukan peningkatan 1 satuan Kemampuan Kerja maka akan mengalami peningkatan terhadap Kinerja 
pegawai sebesar $b_{1}=0,272, b_{2}$ sebesar 0,446 artinya jika instansi melakukan peningkatan 1 satuan pada Lingkungan Kerja maka akan meningkatkan Kinerja pegawai sebesar 0,446, maka dapat dikatakan variabel Kemampuan Kerja dan Lingkungan Kerja terhadap Kinerja Pegawai memiliki pengaruh secara simultan.

\section{Koefisien Determinasi $\left(R^{2)}\right)$}

Koefisien Determinasi $\left(\mathrm{R}^{2)}\right)$ mengukur seberapa jauh kemampuan model dalam menerangkan variabel terikat, dengan menggunakan program SPSS 17.0 for windows dapat dilihat pada tabel berikut:

Tabel 9

Hasil Uji Koefisien Determinasi $\mathbf{R}^{2}$ Model Summary

\begin{tabular}{|c|c|c|c|c|}
\hline Model & \multicolumn{1}{c|}{$\mathrm{R}$} & \multicolumn{1}{c|}{ R Square } & Adjusted R Square & Std. Error of the Estimate \\
\hline 1 & $.791^{\mathrm{a}}$ & .626 & .612 & 2.83117 \\
\hline
\end{tabular}

Sumber : Hasil Olahan Data, Tahun 2017, SPSS versi 17.

Hasil menunjukan R Square atau Koefisien Determinasi sebesar 0,626 dapat diartikan pengaruh Kemampuan Kerja dan Lingkungan Kerja terhadap Kinerja Pegawai Pada Pada Badan Penanggulangan
Bencana Daerah Kabupaten Musi Rawas 62,6\% dan sisanya 37,4\% dipengaruhi variabel lain.

\section{Uji F (Simultan)}

Tabel 10

Hasil Uji F (Simultan)

ANOVA $^{b}$

\begin{tabular}{|l|l|l|l|l|l|l|l|}
\hline Model & & Sum of Squares & Df & & Mean Square & F & Sig. \\
\hline \multirow{2}{*}{1} & Regression & 684.856 & & 2 & 342.428 & $\mathbf{4 2 . 7 2 1}$ & $.000^{\mathrm{a}}$ \\
& Residual & 408.792 & & 51 & 8.016 & & \\
& Total & 1093.648 & & 53 & & & \\
\hline
\end{tabular}

Sumber : Hasil Olahan Data, Tahun 2017, SPSS versi 17

Uji serentak/ simultan (uji F) dilakukan untuk melihat pengaruh dari variabel bebas terhadap variabel terikat secara bersama. Berdasarkan rekapitulasi hasil uji regresi linier berganda, didapat bahwa nilai $\mathrm{F}_{\text {hitung }}$ yang diperoleh adalah 42,721 sedangkan $F_{\text {tabel }}$ dengan penyebut (n-k-l) ( $n$ adalah jumlah data dan $\mathrm{k}$ adalah jumlah variabel independen) sehingga $54-2-1=51$ data pada $\mathrm{F}_{\text {tabel }}$ kolom 51 adalah 3,18 dan tingkat kemaknaan secara serentak sig. F adalah 0,000 dengan kriteria pengujian adalah jika $\mathrm{F}_{\text {hitung }}>\mathrm{F}_{\text {tabel }}$ maka Ho diterima dan jika $\mathrm{F}_{\text {hitung }}<\mathrm{F}_{\text {tabel }}$ maka Ha diterima, maka dapat diketahui bahwa $\mathrm{F}_{\text {hitung }}>\mathrm{F}_{\text {tabel }}$ artinya Ho ditolak dan Ha diterima, bahwa terdapat adanya pengaruh secara simultan (bersama-sama) antara Kemampuan Kerja $\left(\mathrm{X}_{1}\right)$ dan Lingkungan Kerja $\left(\mathrm{X}_{2}\right)$ terhadap Kinerja Pegawai (Y).

Hasil uji serentak/simultan (uji F) ini juga membuktikan bahwa hipotesis ketiga penelitian ini yang berbunyi "Diduga ada pengaruh yang signifikan antara Kemampuan Kerja dan Lingkungan Kerja secara bersama-sama terhadap Kinerja pegawai pada Badan Penanggulangan Bencana Daerah Kabupaten Musi Rawas" terbukti kebenarannya dan hipotesis diterima. 


\section{Hasil}

Hasil penelitian menunjukan bahwa nilai a sebesar 27,903 dan nilai b sebesar 0,556 sesuai dengan persamaan $\mathrm{Y}=\mathrm{a}+\mathrm{bX}$ maka dapat diketahui jika $Y=27,903+0,556 X_{1}$ jadi $a=27,903$ artinya tanpa adanya Kemampuan Kerja maka Kinerja pegawai akan sebesar 27,903 sedangkan b sebesar 0,556 jika pegawai pada Badan Penanggulangan Bencana Daerah Kabupaten Musi Rawas meningkatkan Kemampuan Kerja sebesar 1 satuan maka akan meningkatkan Kinerja pegawai sebesar 0,556. Hasil penelitian menunjukkan bahwa koefisien korelasi antara Kemampuan Kerja terhadap Kinerja Pegawai adalah nilai $\mathrm{R}$ sebesar 0,676 dinyatakan kuat antara variabel Kemampuan Kerja dengan Kinerja Pegawai. Berdasarkan rekapitulasi hasil uji t di atas hubungan antara Kemampuan Kerja Terhadap Kinerja Pegawai dapat dijelaskan, bahwa: Variabel Kemampuan Kerja terhadap Kinerja pegawai Pegawai Pada Badan Penanggulangan Bencana Daerah Kabupaten Musi Rawas menunjukkan nilai $t_{\text {hitung }}=2,957$ lebih besar dari nilai $t_{\text {tabel }}$ $(1,673)$ dengan taraf signifikan $a=5 \%$. Dengan kriteria pengujian adalah jika $t_{\text {hitung }}>\mathrm{t}_{\text {tabel }}$ maka Ho diterima dan jika $\mathrm{t}_{\text {hitung }}<\mathrm{t}_{\text {tabel }}$ maka Ha diterima, maka dapat diketahui bahwa $\mathrm{t}_{\text {hitung }}>$ $\mathrm{t}_{\text {tabel }}$ artinya Ho ditolak dan Ha diterima bahwa terdapat adanya pengaruh variabel Kemampuan Kerja yang signifikan terhadap Kinerja pegawai Pada Badan Penanggulangan Bencana Daerah Kabupaten Musi Rawas. Ini membuktikan bahwa hipotesis pertama yang berbunyi "Diduga ada pengaruh yang signifikan antara Kemampuan Kerja secara parsial terhadap Kinerja pegawai
Pada Badan Penanggulangan Bencana Daerah Kabupaten Musi Rawas" terbukti dan hipotesis diterima.

Hasil penelitian menunjukan bahwa nilai a sebesar 23,170 dan nilai b sebesar 0,622 sesuai dengan persamaan $\mathrm{Y}=\mathrm{a}+\mathrm{bX}$ maka dapat diketahui jika $Y=23,170+0,622 \mathrm{X}$ jadi a $=23,170$ artinya pegawai pada Badan Penanggulangan Bencana Daerah Kabupaten Musi Rawas tanpa adanya Lingkungan Kerjamaka Kinerja pegawai akan sebesar 23,170, sedangkan b sebesar 0,622 jika Pada Badan Penanggulangan Bencana Daerah Kabupaten Musi Rawas meningkatkan Lingkungan Kerja sebesar 1 satuan maka akan meningkatkan Kinerja pegawai sebesar 0,622. Hasil penelitian menunjukan bahwa koefisien korelasi antara Lingkungan Kerja terhadap Kinerja Pegawai adalah nilai $\mathrm{R}$ sebesar 0,750 dinyatakan kuat antara variabel Lingkungan Kerja dengan Kinerja Pegawai.

Berdasarkan rekapitulasi hasil uji t di atas hubungan antara Lingkungan KerjaTerhadap Kinerja Pegawai dapat dijelaskan, bahwa : Variabel Lingkungan Kerja terhadap Kinerja pegawai Pegawai Pada Badan Penanggulangan Bencana Daerah Kabupaten Musi Rawas menunjukkan nilai $t_{\text {hitung }}=\mathbf{4 , 8 1 0}$ lebih besar dari nilai $\mathrm{t}_{\text {tabel }}(\mathbf{1}, \mathbf{6 7 3})$ dengan taraf signifikan $\mathrm{a}=5 \%$. Dengan kriteria pengujian adalah jika $\mathrm{t}_{\text {hitung }}>\mathrm{t}$ tabel maka Ho diterima dan jika $\mathrm{t}_{\text {hitung }}<\mathrm{t}_{\text {tabel }}$ maka Ha diterima, maka dapat diketahui bahwa $t_{\text {hitung }}$ $>t_{\text {tabel }}$ artinya Ho ditolak dan Ha diterima bahwa terdapat adanya pengaruh variabel Lingkungan Kerja yang signifikan terhadap Kinerja Pegawai Pada Badan Penanggulangan Bencana Daerah Kabupaten Musi Rawas. Ini membuktikan bahwa 
hipotesis kedua yang berbunyi "Diduga ada pengaruh yang signifikan antara Lingkungan Kerja secara parsial terhadap Kinerja Pegawai Pada Badan Penanggulangan Bencana Daerah Kabupaten Musi Rawas" terbukti dan hipotesis diterima.

Hasil penelitian regresi liniear berganda menunjukkan bahwa $\mathrm{a}=17,765, \mathrm{~b}_{1}=0,350, \mathrm{~b}_{2}$ $=0,377$ berdasarkan persamaan $Y=a+b_{1} X_{1}+b_{2} X_{2}$ maka dapat diketahui bahwa Ý $=17,765+0,272 \mathrm{X}_{1}$ $+0,446 \mathrm{X}_{2}$. Dengan analisis bahwa a sebesar 17,765 artinya jika pegawai Pada Badan Penanggulangan Bencana Daerah Kabupaten Musi Rawas tidak melakukan tindakan ataupun kegiatan Organisasi dan Lingkungan Kerja maka Kinerja Pegawai akan sebesar 17,765 artinya jika pegawai melakukan peningkatan 1 satuan Kemampuan Kerja maka akan mengalami peningkatan terhadap Kinerja pegawai sebesar $b_{1}=0,272, b_{2}$ sebesar 0,446 artinya jika instansi melakukan peningkatan 1 satuan pada Lingkungan Kerjamaka akan meningkatkan Kinerja pegawai sebesar 0,446, maka dapat dikatakan variabel Kemampuan Kerja dan Lingkungan Kerja terhadap Kinerja Pegawai memiliki pengaruh secara simultan. Hasil menunjukan R Square atau Koefisien Determinasi sebesar 0,626 dapat diartikan pengaruh Kemampuan Kerja dan Lingkungan Kerja terhadap Kinerja Pegawai Pegawai Pada Badan Penanggulangan Bencana Daerah Kabupaten Musi Rawas 62,6\% dan sisanya 37,4\% dipengaruhi variabel lain.

Uji simultan (uji F) dilakukan untuk melihat pengaruh dari variabel bebas terhadap variabel terikat secara bersama. Berdasarkan rekapitulasi hasil uji regresi linier berganda, didapat bahwa nilai $\mathrm{F}_{\text {hitung }}$ yang diperoleh adalah 42,721 sedangkan $F_{\text {tabel }}$ dengan penyebut (n-k-l) (n adalah jumlah data dan $\mathrm{k}$ adalah jumlah variabel independen) sehingga $54-2-1=51$ data pada $\mathrm{F}_{\text {tabel }}$ kolom 51 adalah 3,18. dan tingkat kemaknaan secara serentak sig F adalah 0,000. dengan kriteria pengujian adalah jika $\mathrm{F}_{\text {hitung }}>$ $\mathrm{F}_{\text {tabel }}$ maka Ho diterima dan jika $\mathrm{F}_{\text {hitung }}<\mathrm{F}_{\text {tabel }}$ maka Ha diterima, maka dapat diketahui bahwa $\mathrm{F}_{\text {hitung }}>\mathrm{F}_{\text {tabel }}$ artinya Ho ditolak dan Ha diterima, bahwa terdapat adanya pengaruh secara simultan antara Kemampuan Kerja dan Lingkungan Kerja terhadap Kinerja Pegawai.?

Hasil uji simultan ini juga membuktikan bahwa hipotesis ketiga penelitian ini yang berbunyi "Diduga ada pengaruh yang signifikan antara Kemampuan Kerja dan Lingkungan Kerja secara bersama-sama terhadap Kinerja pegawai Pada Badan Penanggulangan Bencana Daerah Kabupaten Musi Rawas" terbukti kebenarannya dan hipotesis diterima.

\section{PENUTUP}

\section{Kesimpulan}

Berdasarkan hasil analisis data dan pembahasan yang telah diuraikan pada bab sebelumnya, maka dapat diambil kesimpulan Maka persamaan regresinya adalah: Berdasarkan rekapitulasi hasil uji t di atas hubungan antara Kemampuan Kerja Terhadap Kinerja Pegawai dapat dijelaskan, bahwa: Menunjukkan nilai $t_{\text {hitung }}$ $=\mathbf{2 , 9 5 7}$ lebih besar dari nilai $\mathrm{t}_{\text {tabel }}(\mathbf{1 , 6 7 3 )}$ dengan taraf signifikan a $=5 \%$. Dengan kriteria pengujian adalah jika $\mathrm{t}_{\text {hitung }}>\mathrm{t}_{\text {tabel }}$ maka Ho diterima dan jika $\mathrm{t}_{\text {hitung }}<\mathrm{t}_{\text {tabel }}$ maka Ha diterima, maka 
dapat diketahui bahwa $\mathrm{t}_{\text {hitung }}>\mathrm{t}_{\text {tabel }}$ artinya Ho ditolak dan Ha diterima bahwa terdapat adanya pengaruh variabel Kemampuan Kerja yang signifikan terhadap Kinerja pegawai Pada Badan Penanggulangan Bencana Daerah Kabupaten Musi Rawas. Ini membuktikan bahwa hipotesis pertama yang berbunyi “Diduga ada pengaruh yang signifikan antara Kemampuan Kerja secara parsial terhadap Kinerja pegawai Pada Badan Penanggulangan Bencana Daerah Kabupaten Musi Rawas" terbukti dan hipotesis diterima.

Variabel Lingkungan Kerja terhadap Kinerja Pegawai Pada Badan Penanggulangan Bencana Daerah Kabupaten Musi Rawas menunjukkan nilai $t_{\text {hitung }}=\mathbf{4 , 8 1 0}$ lebih besar dari nilai $t_{\text {tabel }}$ $(\mathbf{1}, \mathbf{6 7 3})$ dengan taraf signifikan a=5\%. Dengan kriteria pengujian adalah jika $t_{\text {hitung }}>t_{\text {tabel }}$ maka Ho diterima dan jika $\mathrm{t}_{\text {hitung }}<\mathrm{t}_{\text {tabel }}$ maka Ha diterima, maka dapat diketahui bahwa $\mathrm{t}_{\text {hitung }}>\mathrm{t}_{\text {tabel }}$ artinya Ho ditolak dan Ha diterima bahwa terdapat adanya pengaruh variabel Lingkungan Kerja yang signifikan terhadap Kinerja Pegawai Pada Badan Penanggulangan Bencana Daerah Kabupaten Musi Rawas. Ini membuktikan bahwa hipotesis kedua yang berbunyi "Diduga ada pengaruh yang signifikan antara Lingkungan Kerja secara parsial terhadap Kinerja Pegawai Pada Badan Penanggulangan Bencana Daerah Kabupaten Musi Rawas" terbukti dan hipotesis diterima.

Berdasarkan rekapitulasi hasil uji regresi linier berganda, didapat bahwa nilai $\mathrm{F}_{\text {hitung }}$ yang diperoleh adalah 42,721 sedangkan $\mathrm{F}_{\text {tabel }}$ dengan penyebut (n-k-l) ( $\mathrm{n}$ adalah jumlah data dan $\mathrm{k}$ adalah jumlah variabel independen) sehingga $54-2-1=51$ data pada $\mathrm{F}_{\text {tabel }}$ kolom 51 adalah 3,18 . dan tingkat kemaknaan secara serentak sig
F adalah 0,000. dengan kriteria pengujian adalah jika $\mathrm{F}_{\text {hitung }}>\mathrm{F}_{\text {tabel }}$ maka Ho diterima dan jika $\mathrm{F}_{\text {hitung }}$ $<\mathrm{F}_{\text {tabel }}$ maka Ha diterima, maka dapat diketahui bahwa $\mathrm{F}_{\text {hitung }}>\mathrm{F}_{\text {tabel }}$ artinya Ho ditolak dan Ha diterima, bahwa terdapat adanya pengaruh secara simultan antara Kemampuan Kerja dan Lingkungan Kerja terhadap Kinerja Pegawai. Hasil uji serentak/simultan (uji F) ini juga membuktikan bahwa hipotesis ketiga penelitian ini yang berbunyi "Diduga ada pengaruh yang signifikan antara Kemampuan Kerja dan Lingkungan Kerja secara bersama-sama terhadap Kinerja Pegawai Pada Badan Penanggulangan Bencana Daerah Kabupaten Musi Rawas" terbukti kebenarannya dan hipotesis diterima

\section{Saran}

Berdasarkan kesimpulan yang telah dikemukakan, disampaikan beberapa saran sebagai berikut:

\section{Kemampuan Kerja}

Bagi obyek penelitian hendaknya lebih meningkatkan Kemampuan Kerja pegawai agar bisa meningkatkan Kinerja pegawai. Dimana Kemampuan Kerja terbukti memberikan pengaruh yang signifikan terhadap Kinerja pegawai.

\section{Lingkungan Kerja}

Bagi obyek penelitian hendaknya lebih meningkatkan Lingkungan Kerja pegawai agar mendapatkan kinerja yang maksimal supaya tujuan instansi tercapai. Dimana Lingkungan Kerja terbukti memberikan pengaruh yang signifikan terhadap Kinerja pegawai. 


\section{Kinerja Pegawai}

Bagi obyek penelitian hendaknya semua pegawai dapat mengoptimalkan kinerjanya dalam menyelesaikan pekerjaan dengan meningkatkan kualitas dan kuantitas kerja, meningkatkan efektivitas dan efisiensi kerja, meningkatkan semangat kerja dan kerja sama yang baik serta memiliki tanggung jawab pribadi yang tinggi atas pekerjaannya.

\section{DAFTAR KEPUSTAKAAN}

Anonim. Peraturan Bupati Kabupaten Musi Rawas No. 13 Tahun 2014 tanggal 15 Juli 2014

Depdiknas. 2007. Kamus Besar Bahasa Indonesia, Jakarta: Balai Pustaka

Rahmawanti, Nela Pima. 2014. Pengaruh Lingkungan Kerja Terhadap Kinerja Karyawan (Studi pada Karyawan Kantor Pelayanan Pajak Pratama Malang Utara). Jurnal. Vol. 8 No. 2 Maret 2014
Sugiyono. 2013. Metode Penelitian Administrasi Dilengkapi dengan Metode R\&D. Jakarta: Alfabheta

Sutrisno, Edy. 2015. Manajemen Sumber Daya Manusia. Jakarta: Kencana

Untari, Siti. 2015. Pengaruh Kompetensi dan Lingkungan Kerja terhadap Kinerja Karyawan. Jurnal. Vol. 3 No. 10

Wahyu Setiawan. 2015. Pengaruh Kemampuan Kerja dan Lingkungan Kerja terhadap Kinerja Aparatur Pemerintah di Kantor Camat Kelam Permai Kabupaten Sintang. Jurnal. 2/2015

Wibowo. 2014. Manajemen Kinerja, Jakarta: Rineka Cipta

Wijayanti. 2012. Sumber Daya Manusia. Jakarta: Rineka Cipta Statistical Product and Service Solutions Versi 17.0 